\title{
Cross-Reactivity and Digestive Enzyme Stability of Peach, Korean Cherry, and Hot Pepper
}

\author{
Eun-Jung Kim¹, Yu-Jin Ko', Gyeong-Ran Lee', Hui-Gyeong Seol'², Chang-Min Kang ${ }^{2}$ and Chung-Ho Ryu'* \\ ${ }^{1}$ Division of Applied Life Science (BK21 program), Institute of Agriculture and Life Science, Gyeongsang National University, Jinju 660-701, \\ Korea \\ ${ }^{2}$ Department of Enviromental Toxicology \& Chemistry, Korea Institute of Toxicology, Jinju 660-844, Korea
}

Received August 11, 2012 /Revised November 11, 2012 /Accepted November 22, 2012

\begin{abstract}
Peach (Prunus persica) has been recognized as a food allergen for over 20 years. However, there is little information about cross-reactivity with other foods. The aim of this study was to research cross-reactivity of Korean cherry and hot pepper on patients allergic to peach and its stability by digestive enzyme treatment. Peach, Korean cherry, and hot pepper proteins were extracted and separated by Tricine-SDS-PAGE analysis. The protein extracts had a wide range of molecular weight, from $3 \mathrm{kDa}$ to more than $26 \mathrm{kDa}$, and displayed different patterns of protein bands on Tricine-SDS-PAGE. Peach allergic patients' sera were used to detect the allergenic protein in three samples. Three peach allergic patients' sera reacted strongly with $9 \mathrm{kDa}$ protein of peach, which was the expected lipid transfer protein (LTP) as the major allergen of peach and was detected with anti-LTP1 polyclonal antibody. However, the reactivity of the $23 \mathrm{kDa}$ protein in Korean cherry and hot pepper protein was stronger than that of the $9 \mathrm{kDa}$ protein. The stability of protein extracts on digestive enzyme treatment was examined using simulated gastric fluids (SGF) and simulated intestinal fluids (SIF), in which digestive enzyme stability is one of the characteristics of allergen potentially causing food allergy. Findings confirmed that allergenic proteins in peach, Korean cherry, and hot pepper were not completely digested by SGF and SIF treatments from results of SDS-PAGE analysis. These results confirmed that Korean cherry and hot pepper might cause cross-reactivity in peach allergic patients, and its allergenic proteins have stability against digestive enzymes.
\end{abstract}

Key words : Peach, Korean cherry, hot pepper, cross-reactivity

\section{서 론}

식품 알레르기란 식이형태로 생체에 들어 온 특정의 알레르 겐(allergen)에 대하여 면역계가 과잉으로 반응한 사람에게서 이상 증상이 일어나는 것을 말한다. 알레르기 반응의 원인 식 품으로 계란, 우유, 땅콩, 콩, 밀, 생선 등이 알려져 있고 한국인 에게 빈번하게 알레르기를 일으킨다고 식품의약품안전청에 서 지정한 식품으로는 복숭아, 고등어, 돼지고기, 달걀, 닭고 기, 우유 등이 알려져 있다[22]. 이들 식품에는 다양한 단백질 이 함유되어 있으며 그 중 일부 단백질은 알레르기를 유발시 키는 allergen으로 알려져 있다[8].

특히, 소비가 많은 장미과(Rosaceae) 과일들은 알레르기 반 응의 주요 원인식품으로 보고되고 있다. 복숭아, 아몬드, 체리 (Prunoideae subfamily), 사과, 배(Pomoidaea subfamily)와 딸 기(Rosoideae subfamily)는 장미과(Rosaceae)에 포함된다. 복 숭아는 특히 구강 알레르기 증후군과 관련이 있고 지중해 연 안의 성인 환자에게서 알레르기 반응을 자주 일으킨다[13,15].

\section{*Corresponding author}

Tel : +82-55-772-1905, Fax : +82-55-772-1909

E-mail : ryu@gnu.ac.kr
본 연구에 사용된 앵두 또한 여름철 복숭아와 마찬가지로 국 내에서 많이 소비되고 있는 장미과(Rosaceae) 과일 중의 하나 이다.

고추는 신미료, 착색료, 보존료 및 항산화 기능을 가진 식품 원료로서 매운 맛을 즐기는 한국에서 가장 선호하는 조미료 중 하나이나 지금까지 고추에 대한 연구로는 일반 성분 분석, capsaicine 관련 기능성, 각종 질병에 대한 내성 고추 생산 등 의 보고가 대부분이고 최근 고추에 민감한 환자들에게 식품 알레르기가 유발될 수 있다는 보고도 있다[10].

식물에 존재하는 Lipid Transfer Protein (LTP)는 phytopathogens (bacteria and fungi)이 식물세포 내로 침입하는 것 을 방어하기 위해 생산되는 것으로 알려져 있으며, 특히 복숭 아 및 여러 과채류에 민감성을 가진 사람에게 $\mathrm{IgE}$-매개 식품 알레르기 반응을 유발하는 주요 원인 단백질로 밝혀져 있다 $[4,7,14]$.

이에 본 연구에서는 복숭아 알레르기 증상을 가진 환자 혈 청을 이용하여 앵두와 고추에 대해 교차반응성을 일으킬 수 있는지를 확인하고, 복숭아, 앵두, 고추의 단백질 추출물의 소 화효소 안정성을 조사하고자 한다. 복숭아, 앵두, 그리고 고추 는 국내에서 다량 소비되고 있지만, 이로 인해 발생하는 알레 
르기에 관련된 자료와 연구가 부족한 국내 상황을 고려한다면 본 연구가 알레르기 환자 진단 및 연구에 있어 기초자료로 활용될 것으로 기대한다.

\section{재료 및 방법}

\section{실험재료}

본 실험에 사용된 복숭아(Purunus persica)는 청도 복숭아 시험장으로부터 제공받아 사용하였으며 앵두(Prunus tomentosa Thunberg)는 진주시 중앙 시장에서 구입하고 고추(Capsicum annuun)는 (주)현대종묘로부터 제공받아 본 실험에 사용하였다.

\section{환자 혈청의 확보}

본 실험에 사용된 환자 혈청은 복숭아 섭취 후 구강 알레르 기 및 가려움 등의 증상을 가지는 환자를 대상으로 경상대학 교 대학병원에서 UniCAP 검사를 실시하여 복숭아 특이 $\mathrm{IgE}$ level 2 이상에 속하는 환자 3 명의 혈청과 복숭아 알레르기가 없는 정상인 혈청을 사용하였다.

\section{복숭아, 앵두 및 고추 단백질의 추출}

복숭아, 앵두 및 고추의 단백질은 저온 acetone powder법 $[15,18]$ 으로 추출하였다. 시료는 액체질소로 동결시키며 막자 사발로 미세하게 분쇄하고 시료 $10 \mathrm{~g}$ 에 미리 냉각된 diacetone alcohol (4-Hydroxy-4-methyl-2-pentanone) $20 \mathrm{ml}$ 와 acetone $30 \mathrm{ml}$ 을 혼합하여 $-20^{\circ} \mathrm{C}$ 에서 하루 방치하였다. 시료 용액을 여과지(Whatman No. 2, England)를 이용하여 여과 한 후 acetone/diethyl ether (1:1) 혼합액으로 세척한 후 남은 고형분을 동결건조 하였다. 동결건조 된 시료와 $\mathrm{PBS}$ 를 $1: 15(\mathrm{w} / \mathrm{w})$ 의 비 율로 혼합하여 $4{ }^{\circ} \mathrm{C}$ 에서 1 시간 교반한 후 $17,640 \times g$ 에서 40 분간 원심분리 하였다. 상징액을 $0.45 \mu \mathrm{m}$ membrane filter를 이용 하여 여과 후 동결하여 $-80^{\circ} \mathrm{C}$ 에 보관하면서 본 실험을 수행하 였다.

\section{단백질 농도 측정}

복숭아, 앵두, 고추에서 추출한 단백질의 농도는 Bovine Serum Albumin (BSA, Sigma, Germany)를 표준물질로 이용 하여 Bradford법으로 측정하였다.

Tricine-Sodium dodesylsulfate-polyacrylamide gel electrophoresis (Tricine-SDS-PAGE)

저분자의 주요 알레르겐을 포함한 추출된 단백질의 패턴을 확인하기 위한 Tricine-SDS-PAGE는 15\% separating gel과 5\% stacking gel을 사용하였으며, running buffer는 (+)anode buffer (20 mM Tris, pH 8.45)와 (-)cathode buffer (10 mM Tris, $10 \mathrm{mM}$ Tricine, $0.01 \% \mathrm{SDS}$ )를 사용하였다. Sample의 loading 시 단백질 함량을 $10 \mu \mathrm{g} / \mathrm{well}$ 로 조절하여 loading 후 $100 \mathrm{~V}$ 로
전기영동을 실시하였다. 전기영동이 끝난 gel은 $\mathrm{CBB}$ (Coomassie Brilliant Blue)로 staining 하여 단백질 pattern을 확인하였다.

\section{Immunoblotting 분석}

복숭아, 앵두, 고추의 항원성을 알아보기 위하여 immunoblotting을 실시하였다. 복숭아, 앵두, 고추의 단백질을 추출하 여 단백질 함량을 $10 \mathrm{\mu g} / \mathrm{well}$ 이 되도록 loading하여 SDS-PAGE를 실시한 다음 분리된 단백질 밴드를 PVDF membrane에 transblot apparatus (Bio-rad)을 이용하여 전이하였 다. 전사된 membrane은 $5 \% \mathrm{skim}$ milk로 $4{ }^{\circ} \mathrm{C}$ 에서 하룻밤 동 안 blocking하여 비 특이적 반응 부위를 차단하였다. Membrane에 5\% skim milk로 1차 antibody인 복숭아 알레르 기 환자 혈청을 100 배 또는 anti-lipid transfer protein1 antibody (Fitzgerald industries international Inc., USA)을 400배 희석한 용액을 가하여 3시간 동안 교반하면서 반응시킨 후 washing buffer (Tris-buffered saline $(20 \mathrm{mM}, \mathrm{pH}$ 8.2) containing $0.1 \%$ Tween-20)로 3 회 세척하였다. 2차 antibody인 peroxidase-conjugated antihuman IgE를 5\% skim milk에 100 배 희석한 용액을 가하여 2시간 동안 반응시킨 후 세척한 다음 membrane에 있는 peroxidase를 enhanced chemiluminescent (ECL) western blotting detection system으로 검출하였다[9].

\section{인공위액(Simulated gastric fluid (SGF)) 처리}

복숭아, 앵두, 고추 단백질 추출물의 인공위액 처리는 Astwood 법[1]을 변형하여 실험하였다. $0.32 \%$ pepsin A를 함 유한 인공위액에 최종 단백질 농도가 $1 \mu \mathrm{g} / \mathrm{\mu l}$ 가 되도록 추출된 단백질을 녹여 $37^{\circ} \mathrm{C}$ 에서 shaking하면서 각각 $0,0.5,5,15,30$ 및 60 분에 수집하여 $200 \mathrm{mM} \mathrm{Na} 2 \mathrm{CO}_{3}$ 을 $60 \mu \mathrm{l}$ 가하여 반응 정지 시킨 후 $-20^{\circ} \mathrm{C}$ 에 보관하면서 이후 실험을 진행하였다.

\section{인공장액(Simulated intestinal fluid (SIF)) 처리}

복숭아, 앵두, 고추 단백질 추출물의 인공장액 처리는 Pharmacopoeia [20]에 따른 방법으로 $10 \mathrm{mg} / \mathrm{ml}$ pancreatin을 $0.05 \mathrm{M} \mathrm{KH}_{2} \mathrm{PO}_{4}$ (pH.7.5) 녹여 사용하였다. $37^{\circ} \mathrm{C}$ 에서 10 분간 예열한 인공장액에 단백질 최종 농도가 $0.5 \mu \mathrm{g} / \mu \mathrm{l}$ 가 되도록 녹인 후 shaking 배양하면서 각 $0,5,30,60$ 및 120 분에 각 단백질 시료를 microtube에 수집한 후 $-20^{\circ} \mathrm{C}$ 에 보관하면서 실 험에 사용하였다.

\section{결과 및 고찰}

\section{SDS-PAGE에 의한 단백질의 패턴}

복숭아, 앵두, 고추에서 추출된 단백질을 SDS-PAGE를 실 시한 후, 단백질 패턴을 확인하여 Fig. 1에 나타내었다. 복숭아 는 앵두나 고추보다 $9 \mathrm{kDa}$ 부근의 단백질 밴드가 상대적으로 


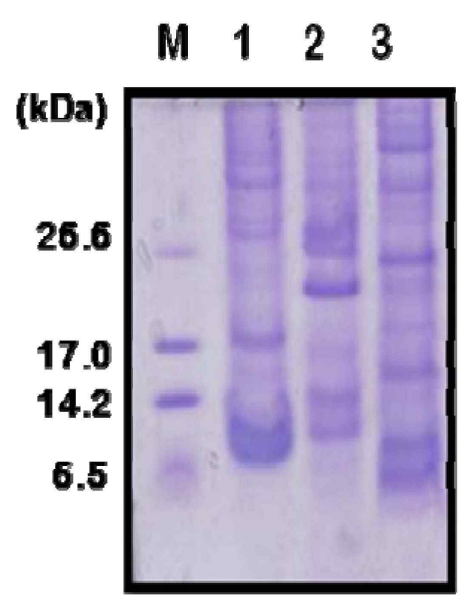

Fig. 1. SDS-PAGE of protein extracts from peach, Korean cherry and hot pepper. Lane M: molecular weight marker, Lane 1: peach, Lane 2: Korean cherry, Lane 3: hot pepper

진하게 나타났으며, 앵두의 경우 $9 \mathrm{kDa}$ 부근의 밴드를 포함하 여 14,23 그리고 $27 \mathrm{kDa}$ 부근에서 진한 단백질 밴드를 확인할 수 있었다. 고추 단백질 추출물을 살펴보면 $5 \mathrm{kDa}$ 의 밴드가 강하게 나타났으며 그 외에 $8 \mathrm{kDa}$ 부근과 $15 \sim 26 \mathrm{kDa}$ 부근의 단백질 등 상대적으로 복숭아와 앵두에 비해 다양한 크기의 단백질 밴드가 분포하는 것을 확인할 수 있었다.

앵두와 고추에 대한 복숭아 알레르기 환자의 $\operatorname{lgE}$ 교차반응성 복숭아 알레르기 환자 혈청을 이용하여 앵두와 고추의 단백 질 추출물에 대한 교차반응성을 확인하였다(Fig. 2). (A) (C) 는 복숭아에 대해 알레르기 증상을 나타내는 환자 혈청을, (D) 는 정상인 혈청을 사용하였다. 복숭아 단백질 추출물에 대해 서 3명의 환자 모두 복숭아의 주요 알레르겐인 LTP로 예상되 는 $9 \mathrm{kDa}$ 부근의 단백질 밴드와 강한 반응성을 나타내었다. 반면, 앵두 단백질 추출물과 복숭아 민감성 환자 혈청의 반응
성을 확인해 본 결과 환자에따라 $9 \mathrm{kDa}$ 부근에 대한 반응성이 달랐으나 $20 \mathrm{kDa}$ 부근의 밴드에 3 명의 환자 혈청 모두 강하게 반응하는 것을 확인 할 수 있었다. 복숭아 알레르기 환자의 혈청이 고추 단백질 9 및 $23 \mathrm{kDa}$ 부근의 밴드 및 고분자량의 밴드에서 반응성을 나타낸 것으로 보아, 복숭아 알레르기를 가진 환자가 앵두 및 고추를 섭취 할 경우 교차반응성을 일으 킬 가능성이 있는 것으로 생각된다. 반면, 정상인 혈청은 세 가지 과채류 추출 단백질에 대한 반응성이 없음을 확인 할 수 있었다. Ebner 등[5]과 Bauer 등[2]은 꽃가루와 사과 및 쑥 과 샐러리의 교차반응성에 관한 연구를 하였으며 Leitner 등 [11]도 고추와 샐러리 등의 교차반응성에 관한 연구를 하였다. 또한 Blanco 등[3]은 라텍스(Latex) 알레르기를 가진 환자가 복숭아에 대해 교차반응을 가지는 것을 확인하여 채소류와 과일의 교차반응성의 가능성에 대해 시사하였으나 본 연구에 서는 한국에서 재배되고 소비되는 품종의 과채류를 이용하여 한국인에게 일어날 수 있는 알레르기 교차반응성을 연구한 것에 큰 의의가 있다고 사료되며 특히 복숭아와 고추의 교차 반응성에 관한 연구는 전무한 실정으로 알레르기 연구의 기초 자료로 본 연구결과를 활용할 수 있을 것이다.

복숭아, 앵두, 고추 단백질 추출물에 대한 anti-lipid transfer protein I antibody의 반응성

장미과(Rosaceae)과에 속하는 대표적인 과일인 복숭아, 앵 두, 살구 등을 구강으로 섭취 시 알레르기 반응을 일으키는 주요 알레르겐으로 저분자량의 단백질인 LTP가 알려져 있다 [6,17]. 이 LTP는 $9 \mathrm{kDa}$ 정도의 분자량을 가지며, Rosaceae과 에 속하는 과일 뿐 아니라 고추를 비롯해 상추, 옥수수, 깻잎 등의 식물소재에 널리 분포하는 것으로 보고되어 있다[6,16]. 우리나라에서 즐겨먹는 과일인 복숭아, 앵두와 고추에 항원성 단백질인 LTP가 존재하는지를 확인하기 위해 각 단백질 추출 물과 polyclonal anti-lipid transfer protein I antibody를 이용

(A)

(B)

(C)

(D)
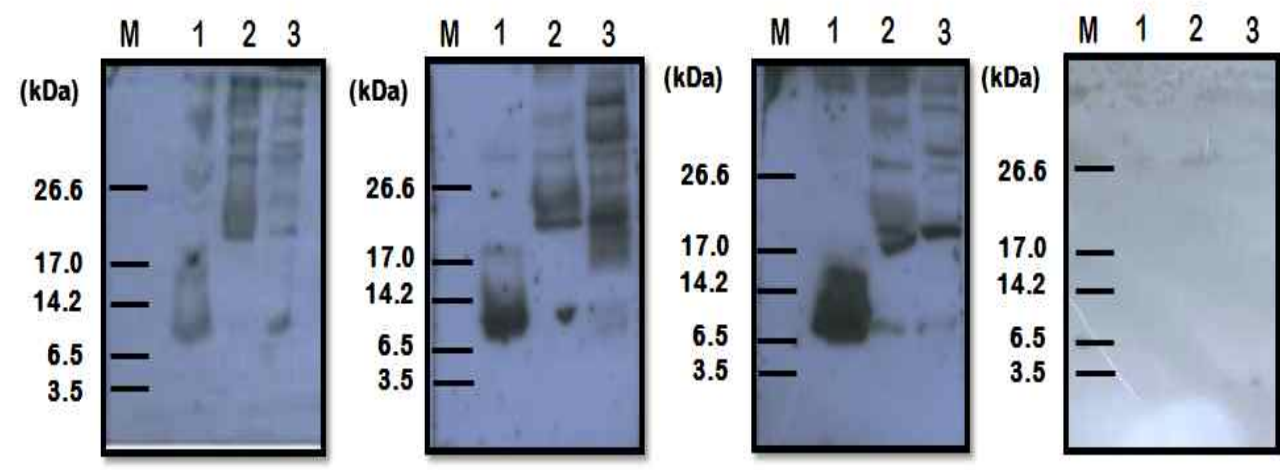

Fig. 2. Immunoblotting with peach allergic patients' sera against protein extracts of peach, Korean cherry and hot pepper. (A) (C): individual peach allergic patients' sera, (D): non-allergic people's serum, Lane M: molecular weight marker, Lane 1: peach, Lane 2: Korean cherry, Lane 3: hot pepper 
하여 western blotting을 실시하였다(Fig. 3). Lane 1의 복숭아 단백질 추출물은 $9 \mathrm{kDa}$ 부근에서 매우 강한 항원-항체 반응을 보였고 앵두와 고추에서도 미약하게 반응성을 가지는 것을 확인하였다. 복숭아에 알레르기를 가진 환자들이 앵두와 고추 를 섭취했을 경우에도 LTP의 교차반응에 의한 알레르기 증상 이 발현될 수 있을 것으로 예상된다.

\section{인공위액 처리에 따른 복숭아, 앵두 및 고추 단백질 추출물의 안정성}

복숭아, 앵두 및 고추 단백질 추출물을 $0.32 \%$ pepsin A를 함유한 인공위액으로 처리하며 반응시간에 따른 단백질 분해 정도를 Fig. 4 에 나타내었다. 복숭아, 앵두 및 고추 추출물의 $9 \mathrm{kDa}$ 부근의 LTP로 추정되는 단백질이 인공위액 처리 시 공통적으로 분해되지 않는 것을 확인할 수 있었으며, 앵두와 고추는 $9 \mathrm{kDa}$ 뿐만 아니라 $23 \mathrm{kDa}$ 부근의 단백질도 60 분간의

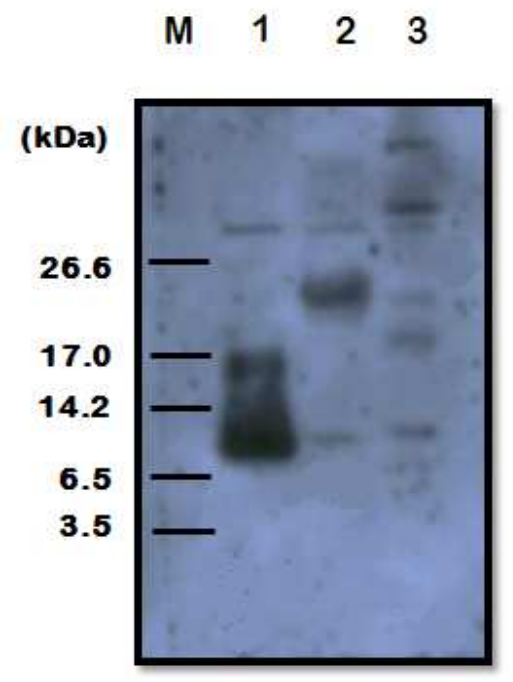

Fig. 3. Western blotting with anti-lipid transfer protein 1 antibody on peach, Korean cherry and hot pepper protein extracts. Lane M: molecular weight marker, Lane 1: peach, Lane 2: Korean cherry, Lane 3: hot pepper pepsin효소처리 후에도 분해되지 않고 안정성을 가지는 것을 확인하였다. 식품알레르기를 일으키는 항원성 단백질 즉, 알 레르겐의 특성 중의 하나가 소화효소를 함유한 인공위액에 분해되지 않고 안정성을 가지는 것으로 알려져 있어[12] 복숭 아, 앵두 및 고추에도 lipid transfer protein 및 thaumatin like protein 등 이미 알려진 주요 알레르겐 외 상당한 minor 알레 르겐이 존재하므로 알레르기 유발 원인이 될 수 있을 것으로 생각된다. 한편, Takagi K [19] 및 Venkatachalam M 등[21]에 따르면 pepsin과 시료의 처리 농도에 따라 단백질의 효소에 대한 안정성이 차이 날 수 있다고 알려져 있어 향후 실험에 있어서 처리 비율에 따른 효소안정성을 확인해 볼 필요성이 있을 것이다.

\section{인공장액 처리에 따른 복숭아, 앵두, 고추 단백질 추출물의 안정성}

복숭아, 앵두 및 고추 단백질 추출물을 $0.1 \%$ pancreatin을 함유한 인공장액으로 처리하여 시간에 따른 안정성을 SDS-PAGE를 통해 확인하였다(Fig. 5). 인공장액 처리 시 복숭 아 단백질은 9 및 $17 \mathrm{kDa}$ 부근의 밴드가 120 분 경과 후에도 완전히 분해되지는 않지만 앵두와 고추 단백질은 반응 시간이 늘어남에 따라 미약하게 분해되는 것을 확인하였고 그 외의 단백질도 인공장액처리에 의해 분해됨을 알 수 있었다. 앵두 단백질 추출물은 복숭아 단백질 추출물과 마찬가지로 $9 \mathrm{kDa}$ 부근의 단백질을 비롯하여 또 다른 알레르겐으로 예상되는 20 및 $26 \mathrm{kDa}$ 의 단백질이 장액처리에 대한 안정성을 나타내었 다. 고추 단백질 추출물은 $7 \sim 9 \mathrm{kDa}$ 및 $23 \mathrm{kDa}$ 단백 질이 인공 장액처리 시에도 거의 분해되지 않았다. Fuchs and Astwood [1]에 따르면 알레르겐의 경우, 인공위액 처리 시 낮은 안정성 을 가지나 인공장액 처리에서는 보다 더 안정성을 가질 수 있다고 보고한 바 있어 알레르겐의 특성에 따라 위액 및 장액 처리에 따른 안정성이 다른 것으로 사료된다. 또한 앞서 $\mathrm{im}-$ munoblotting 시 복숭아 알레르기 증상을 보이는 환자 혈청과 강한 반응성을 가졌던 앵두와 고추의 단백질이 소화효소처리

(A)

(B)

(C)

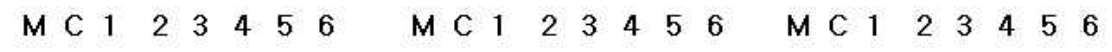

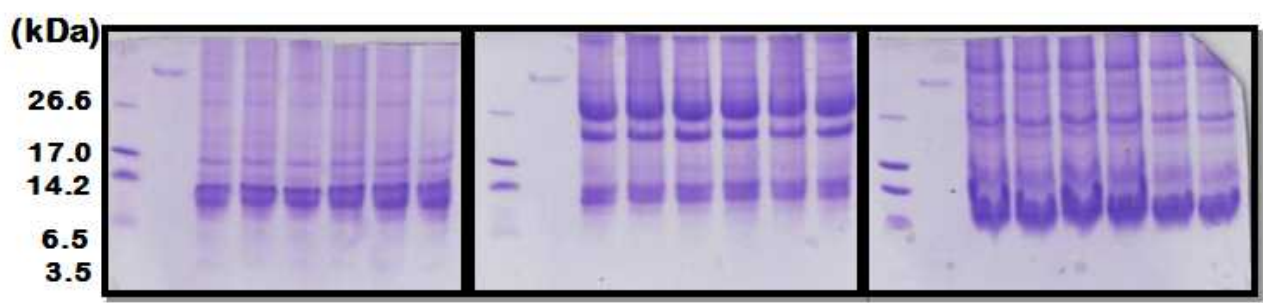

Fig. 4. Effect of SGF treatment on peach, Korean cherry and hot pepper protein extracts. (A) (C): peach, Korean cherry and hot pepper protein extracts, Lane M: molecular weight marker, Lane C: simulated gastric fluid (SGF). Lane 1 6: digested peach protein extracts by SGF at $0,0.5,5,15,30$ and $60 \mathrm{~min}$, respectively. 
(A) (B) $\quad$ (C)

$\begin{array}{llllllllllllllllllll}\text { M C } & 1 & 2 & 3 & 4 & 5 & \text { M C } & 1 & 2 & 3 & 4 & 5 & \text { M } & \text { C } & 1 & 2 & 3 & 4 & 5\end{array}$

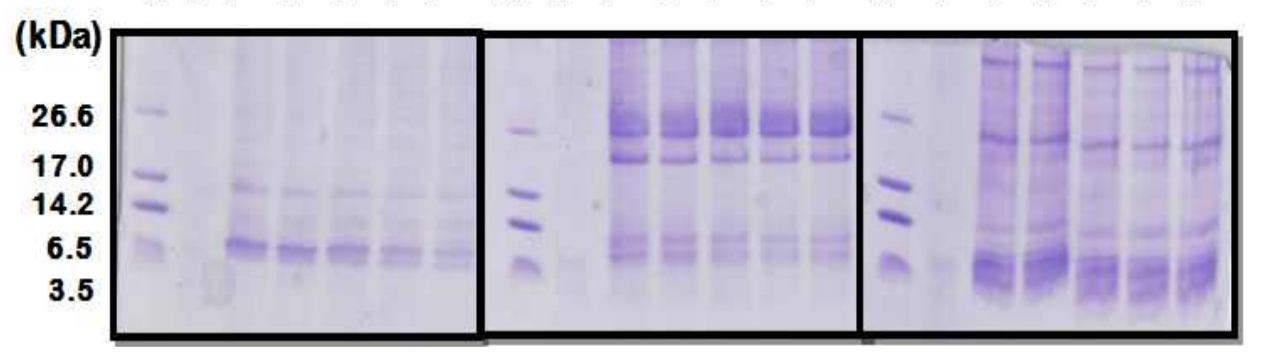

Fig. 5. Effect of SIF treatment on peach, Korean cherry and hot pepper protein extracts. $(\mathrm{A}) \sim(\mathrm{C})$ : peach, Korean cherry and hot pepper protein extracts, Lane M: molecular weight marker, Lane C; simulated intestinal fluid (SIF), Lane 1 5: digested peach protein extracts by SIF at 0, 5, 30, 60 and $120 \mathrm{~min}$, respectively

시 분해되지 않아 인공위액 및 장액에 안정성을 가지는 알레 르겐으로 추측된다.

본 실험을 통해 복숭아, 앵두 그리고 고추 단백질 추출물에 서 복숭아 알레르기 환자의 혈청과 반응하는 항원성 단백질이 존재하는 것으로 미루어 교차반응성을 일으킬 수 있고, 소화 효소처리에 안정한 항원 고유의 특성을 가지고 있는 것을 확 인 할 수 있었다. 따라서 이번 연구는 한국인이 즐겨 섭취하는 복숭아, 앵두, 고추의 알레르기 유발 단백질과 그 특성을 확인 함으로써 복숭아 알레르기 유발에 대한 원인 규명 및 기초자 료로 활용 될 수 있을 것이라 사료된다.

\section{감사의 글}

본 연구는 경상대학교 Brain Korea 21 program의 지원으로 수행되었기에 이에 감사드립니다.

\section{References}

1. Astwood, J. D., Leach, J. N. and Fuchs, R. L. 1996. Stability of food allergens to digestion in vitro. Nat. Biotechnol. 14, 1269-1273.

2. Bauer, L., Ebner, C., Hirschwehr, R., Wüthrich, B. Pichler, C., Fritsch, R., Scheiner, O. and Kraft, D. 1996. IgE cross-reactivity between birch pollen, mugwort pollen and celery is due to at least three distinct cross-reacting allergens. Immunoblot investigations of the birch-mugwort- birchcelery syndrome. Clin. Exp. Allergy 26, 1161-1170.

3. Blanco, C., Carrillo, T., Castillo, R., Quiralte, J. and Cuevas, M. 1994. Latex allergy: clinical features and crossreactivity with fruits. Ann. Allergy 73, 309-314.

4. Duffort, O. A., Polo, F., Lombardero, M., Díaz-Perales, A., Sánchez-Monge, R., García-Casado, G., Salcedo, G. and Barber, D. 2002. Immunoassay to quantify the major peach allergen Pru p 3 in foodstuffs. differential allergen release and stability under physiological conditions. J. Agric. Food Chem 50, 7738-7741.

5. Ebner, C., Birkner, T., Valenta, R., Rumpold, H., Breitenbach, M., Scheiner, O. and Kraft, D. 1991. Common epitopes of birch pollen and apples. Studies by Western and Northern blot. J. Allergy Clin. Immunol. 88, 588-595.

6. Jean, C. K. 1996. Lipid transfer protein in plants. Annu. Rev. Plant Physiol. Plant Mol. Biol. 47, 627-654.

7. Kader, J. C. Proteins and the intracellular exchange of lipids. I. Stimulation of phospholipid exchange between mitochondria and microsomal fractions by proteins isolated from potato tuber. 1975. Biochim Biophys. Acta. 380, 31-44.

8. Kay, A. B. and Coombs, R. R. A. 1985. Allergy and allergy disease pp. 963-968, $2^{\text {nd }}$ eds., Blackwell science.

9. Laemmli, U. K. 1970. Cleavage of structural proteins during the assembly of the head of bacteriophage T4. Nature 227, 650-680.

10. Lee, J. O., Kim, E. J., Ko, Y. J., LEE, S. I., Lee, W. S. and Ryu, C. H. 2009. Allergenicity of hot peppers in Kor. J. Food Sci. Biotechnol. 18, 317-322.

11. Leitner, A., Jensen-Jarolim, E., Grimm, R., Wüthrich, B., Ebner, H., Scheiner, O., Kraft, D. and Ebner, C. 1998. Allergens in pepper and paprika. Immunologic investigation of the celery-birch-mugwort-spice syndrome. Allergy 53, 36-41.

12. Moreno, F. J. 2007. Gastrointestinal digestion of food allergens: Effect on their allergenicity. Biomed Pharmacother. 61, 50-60.

13. Ortolani, C., Ispano, M., Pastorello, E. A., Bigi, A. and Ansaloni, R. 1998. The oral allergy syndrome. Ann. Allergy 61, 47-52.

14. Pastorello, E. A., Farioli, L., Pravettoni, V., Ortolani, C., Ispano, M., Monza, M., Baroglio, C., Scibola, E., Ansaloni, R., Incorvaia, C. and Conti, A. 1999. The major allergen of peach (Prunus persica) is a lipid transfer protein. J. Allergy Clin. Immunol. 103, 520-526.

15. Pastorello, E. A. and Trambaioli, C. 2001. Isolation of food allergens. J. Chromatogr B. Biomed Sci. Appl. 756, 71-84. 
16. San Miguel-Moncín, M., Krail, M., Scheurer, S., Enrique, E., Alonso, R., Conti, A., Cisteró-Bahíma, A. and Vieths, S. 2003. Lettuce anaphylaxis: identification of a lipid transfer protein as the major allergen. Allergy 58, 511-517.

17. Sánchez-Monge, R., Lombardero, M., García-Sellés, F. J., Barber, D. and Salcedo, G. 1999. Lipid-transfer proteins are relevant allergens in fruit allergy. J. Allergy Clin. Immunol. 103, 514-519.

18. Son, D. Y., Scheurer, S., Hoffmann, A., Haustein, D. and Vieths, S. 1999. Pollen-related food allergy: Cloning and immunological analysis of isoforms and mutants of Mal d 1, the major apple allergen, and Bet v 1, the major birch pollen allergen. J. Eur. Nutr. 38, 201-221.

19. Takagi, K., Teshima, R., Okunuki, H. and Sawada, J. 2003. Comparative study of in vitro digestibility of food proteins and effect of preheating on the digestion. Biol. Pharm Bull. 26, 969-973.

20. The United States Pharmacopeias 23 \& The National
Formulary 18. 1995. Simulated gastric fluid and simulated intestinal fluid, TS. pp. 2053. The United States Pharmacopeial Convention.

21. Venkatachalam, M., Teuber, S. S., Peterson, W. R., Roux, K. H. and Sathe, S. K. 2003. Antigenic stability of pecan [Carya illinoinensis (Wangenh.) K. Koch] proteins: Effects of thermal treatments and in vitro digestion. J. Agric. Food Chem 54, 1449-1458.

22. Yun, H. J., Lim, S. Y., Hur, J. M., Lee B. Y., Choi, Y. J., Kwon, J. H. and Kim, D. H. 2008. Change of Nutritional compounds and texture characteristics of Peaches (Prunus persica L. Batsch) during post-irradiation storage at different temperature. Kor. J. Food Preserve 15, 377-384.

23. Zuidmeer, L., Salentijnw, E., Rivasz, M. F., Manceboz, E. G., Asero R., Matosw C. I., Pelgromw, K. T., Gilissenw, L. J. and van Ree, R. 2006. The role of profilin and lipid transfer protein in strawberry allergy in the Mediterranean area. Clin. Exp. Alllergy 36, 666-675.

초록 : 복숭아, 앵두, 고추의 교차반응성 및 소화효소안정성

김은정 ${ }^{1} \cdot$ 고유진 ${ }^{1} \cdot$ 이경란 ${ }^{1} \cdot$ 설희경 ${ }^{2} \cdot$ 강창민 $^{2} \cdot$ 류충호 $^{1}{ }^{*}$

('경상대학교 응용생명과학부(BK 21 프로그램) · 농업생명과학연구원, ${ }^{2}$ 안전성평가연구소· 경남환경독성본부)

복숭아는 오래 전부터 알레르기를 일으키는 식품으로 알려져 있으나 특정 식품과의 교차반응에 대한 연구는 부족한 실정이다. 본 연구에서는 한국에서 재배되고 있는 복숭아, 앵두, 고추의 단백질을 추출하여 복숭아 알레르 기를 가진 환자가 앵두와 고추에 대해 교차반응성을 일으키는지 확인하고 이 단백질들의 소화효소처리에 따른 안정성을 조사하였다. 복숭아, 앵두 및 고추 단백질 추출물은 Tricine-SDS-PAGE상에서 $3 \mathrm{kDa}$ 부터 $26 \mathrm{kDa}$ 이상 까지 넓은 범위의 단백질 분포를 보였으나 각기 다른 패턴을 가지는 것을 확인하였다. 복숭아 단백질의 항원성을 확인하기 위해 복숭아 민감성 환자의 혈청과의 $\mathrm{IgE}$ 반응성을 확인한 결과, 환자 혈청은 모두 복숭아의 주요 항원 성 단백질 lipid transfer protein로 예상되는 $9 \mathrm{kDa}$ 부근에서 강한 IgE결합력을 보였으며 또한 $9 \mathrm{kDa}$ 단백질이 anti-LTP1 polyclonal antibody에 의해 검출되는 것을 확인하였다. 앵두와 고추 단백질 추출물은 $23 \mathrm{kDa}$ 부근에 서의 $\mathrm{IgE}$ 결합력이 $9 \mathrm{kDa}$ 과의 반응성보다 크게 나타났다. 복숭아, 앵두 및 고추의 소화효소에 대한 안정성을 SDS-PAGE 상에서 확인한 결과, 복숭아, 앵두 및 고추의 항원성 단백질은 인공 위액 및 장액에 의해 완전히 분해 되지 않아 알레르기를 유발할 잠재성이 있는 것을 확인할 수 있었다. 본 연구 결과를 바탕으로, 복숭아, 앵두 및 고추 단백질 추출물이 소화효소처리에 안정성을 가지는 특성을 가지며 복숭아 알레르기 증상을 가지는 사람에게 앵두 및 고추는 교차반응성을 일으킬 가능성이 크다는 것을 확인할 수 있었다. 